\title{
WHEN IS A BANK THE BONA FIDE OIVNER OF A CHECK LEFT FOR DEPOSIT OR COLLECTION?
}

The boundary of our inquiry may be more closely defined by leaving out all cases that were the subject. of special agreenent, ${ }^{2}$ or that were so endorsed by the depositor as to retain intentionally his ownership. ${ }^{2}$ These include a large number and involve the application of no principle save the most gencral one, that the agreement must be founded on proper authority, or be within proper legal limitations.

At the outset, it may be stated that the courts have always maintained that the title to checks deposited by, and credited to, a depositor who is a contemporaneons debtor, passes at once to the lank absolutely. ${ }^{3}$ This principle is so strongly fortificd by reason and precedent that the mere statement of the rule will suffice." For the same reason, after an idvance has been made thereon, the bank becomes either the absolute owner or a lienor for the amount of the advance." The rule is equally clear that a depositor who is credited with a check, and not as cash, retains his

'Richardson v. Louiscille Bkg. Co., 36 C. C. A. 307 ; Fikst National Bunk of Elkhart v. Armstrong, 39 Fed. 231 (C. C.); Manufacturers' National Bank v. Continental Bank, 148 Mass. 553 .

${ }^{2}$ Bcal v. City of Somerzille, I C. C. A. 548 ; Lrin v. Bank, 5 Dill 107; First National Bank v. Reno Co. Bank, I MeCrary 491; Sweeny v. Easter, I Wall 166; II hite v. National Bank, 102 U. S. 658; Cecil Bank v. Farmers' Bank, 22 Mit. 148; Afechanics' Bank v. Valley Parking Co., zo Mo. 643; Mfilliken s. Shapleigh, 36 Mo. 598

'Tilus v. Mrihunics' N'ational Bank, 35 N. J. Law 588, 592.

- Ralbaich v. Frclinghuysen, 15 Fed. 675, 682; Armstroug v. National Bank of Boycrtoun, $90 \mathrm{Ky} .431$; Taft v. Qrissigantond National Bank, 172 Mass. 363.

- Mfetropolitan Nat. Bank v. Loyd, 90 N. Y. 530; Armstrong ४. Nat. Bank of Boyertoa'n. go Ky. 431, 436; Balbach v. Frelinghuysen. 15 Fed. 675; Scull v. Ocean Bank, 23 N. Y. 289; Giles v. Perkins, 9 East 12, 14 
ownership." And, likewise, a depositor who is credited with a check provisionally in anticipation of payment, but having no right to draw against the sum credited.'

We now approach the class of cases that are the special subject of inquiry-those that are deposited and credited to the depositor with the right to draw inmediately for the amount of the credit. Some courts have held that the ownership was not transferred by such action on the part of the bank; other courts have maintained the opposite gromul. The unquestioned tendency is to hold that the effect of such a transfer is to vest their title in the bank. The highest court in the land recently adopted the rule, using the form of expression by the Court of Appeals of New York, which said: 8 "The general doctrine that upon a deposit made by a customer, in a bank, in the ordinary course of business, or of money, or of drafts or checks received and credited as money, the title to the money or to the drafts or checks, is immediately vested in and becomes the property of the bank, is not open to question."

It follows that, if the title thus passes to the bank, the depositor's control over them ceases. Suppose a depositor should wish to recall a check before collection on which no advance has been made, would the bank surrender it? Would it surrender a note that had been discounted, the

- Builic v. Augusia Sav. Bank, 95 Ga. 277, 280; St. Lauis and San Francisco Railroud Co. v. Johnston, 23 Blatch. 492; Thompson v. Giles, 2 Barn and Cres. 422.

Midland Nat. Bank จ. Brightwell, 148 Mo. 358; Freeholders of County of Xi iddlescx v. State Bank, 32 N. J. Eq. 467; Beal v. City of Somcrville, 5 U. S. App. If; Hazlctt v. Conmercial National Bank, I32 Pa. I18; Rapp v. National Srcurity Bank, 136 Pa. 426; National Butchers'. and Drovers' Bank v. Hubbcll, II7 N. Y. 3\&4; Richardson v. New Orlcans Coffec Co., 43 C. C. A. 583; First National Bank of Trinidad .v. First National Bank of Denver, 4 Dill. 290; Levi v. National Bank of Missouri, 5 Jill. ros; Armstrong ". National Bank of Boycrioum, 9 Ky. 435, 437: Midland National Bank v. Brightwell, 148 Mo. 358

"Cragie v. Hadley, 99 N. Y. I3I.

- Burton v. United States, I96 U. S. 283 , 302, citing Thompson v: Riggs, 5, IVall $6 \sigma_{3}$; Marinc Bank v. Fulton Bark, 2 Wall 252; Scammon v. Kimball, 92 S. C. 362, $369 ;$ Davis v. Elmira Sav. Bank, 161 U. S. 275, 288; Acbi v. Bank of Ezansrille, I24 Wis. 73; Flannery v. Coates, 80 Mo. 444 ; Aycrs v. Farmers' and Mcrchants' Bank, 79 Mo. $42 \mathrm{x}$. 
amount of which had been credited to, but not drawn by, the depositor, on the maker's request? If the title to the checks thus passes to the bank on crediting them, then it follows that if the bank afterward re-delivers them to the depositor at his request, this is done as a favor, and not as a right. ${ }^{10}$ Surely, absolute ownership by the bank is inconsistent with the right of recall by the depositor.

Clearly established as the rule is, there certainly are some serious difficulties with the foundation on which it rests. There is no consideration for the transfer of the title un- less this be the right to draw the money represented by the checks. This, however, is a shadowy thing, for unquestionably the bank has a right of withdrawing that credit at any time before the depositor has used it. The depositor, therefore, receives at most a qualified right to draw which may be defeated by the sole action of the bank." Furthermore, if the bank had not the right to withdraw its credit, it would hardly dare make such an advance, for the act of the bank rightly considered is a loan, or rather an agrement to lend, for such a period of time letween the actual deposit and collection of his checks as the depositor may desire.

The riglit to cancel the credit has led some courts to hold that a transfer was not effected by crediting; in other worls, ${ }^{11}$ that this right was inconsistent with absolute ownership; but more frequently the courts have held otherwise. ${ }^{12}$ In a well reasoned case decided by the Supreme Court of Kansas, it was said: "It may be conceded that if, after due and legal effort to collect a check, it should be dishonored, the bank would have the right to charge the amount of it to the depositor's account. Whether this

\footnotetext{
"Mctropolitan National Bank v. Loyd. go N. Y. $530,535$.

"N'aticnal Butchers' and Druz'crs' Bank v. Hubbcll, 117 N. Y. 384, $393,394$.

'Alyrs v. Farners' \& Mfcrchants' Bank, 79 Mo. 42t; Flannery $\nabla$. Coulis \&o Mo. 444: First Nat. Bank of F:lkhurl v. Armstrong. 39 Fed. (C. C.) 231, 233: Riserside Bank v. Woodhawen Jurction Land Co., 34 N. Y. Alp. Div. 359.
} 
right may be said to rest merely on the custom of banks, or whether the custom has been crystallized into a rule, and the right now may be said to be an implied condition attaching to the transfer of the paper, makes no difference. It is, nevertheless, in strictness, the right of an endorsee against an endorser, and hence is not, in any sense, inconsistent with ownership."18

On three grounds, then, the right of ownership may be maintained with the right of charging a check back if it is not paid. First, the right is not absolute in a technical sense. Though that word has been occasionally used by the courts in that comnection, yet it has been used inadvertently, since absolute ownership and the right of charging . back are manifestly inconsistent. The courts have doubtless meant essential or conditional ownership, since the occasion for charging checks back rarely occurs, considering the vast use of checks in modern society. Second, if a check could not be charged back, a depositor would ordinarily save nothing, since he would be liable on his endorsement. This is a liability independent of the trainsfer by the deprositor of ownership to the bank. But as the legal enforcement of this right by suit may be prevented by permitting the collecting bank to charge the check back; this can be done. ${ }^{14}$ Third, as the seller of personal property impliedly warrants the title, the purchaser is no less an absolute owner because he has redress against the seller should his title fail.

But if the title is absulutely transferred to the bank by crediting with the right to draw, in the technical sense in

${ }^{12}$ Noble v. Doughten. 72 Kan. 336, 345.

"In Mitropolitan Nat. Bank v. Loyd, 25 IHun. 10r, 106, Daniels, J. said: "As this check was tran'sferred to and received by the bank it became its properiy, and the fact that it had the right in case of nonpayment, upon presentment, to charge the amount of it back in the account of the customer, did not change the nature of the transaction through which it was reccived, for that right resulted, not from any agrecinent existing between the parties upon the subject, but from the rights which the lank might derive fron proceedings afterwards taken to charge the depositor as the endorser." 
which the term "absolute" is used, then the right to charge the eheck back if the collecting bank fails without any negligence on its part to complete the collection, clearly does not exist. This is a logical rule and has been upheld by the Supreme Court of Massachusetts. Nevertheless, a bank has a remedy on the depositor's endorsement, for this is an independent liability. On the other hand, the Supreme Court of the United States has declared that "the mere credit of a check upon the books of a bank, which may be cancelled at any time, does not make the bank a bona fide purcliaser for value." 18 This may be easily reconciled with the rule in the Burton case by also holding that technically when the ownership of a check passes, it camnot be charged back. Yet doubtless that court would hold, as the courts in New York, Kansas and other States have held, that as the depositor is liable on his independent contract of endorscment, the easier way of adjusting the difficulty is to permit the collecting bank to charge back the uncollected check.

By such an interpretation of the decisions, they can be harmonized with the rule that prevails when a note is discounted for a borrower who is credited with the amount. On such occasions, it has been decided that a bank is not a bona fide holder intil it has paid the money. Let us begin our review with Daniel: "The apparent purchase must have been a purchase in fact and not a mere bookkeeping entry. Mere discount and credit do not of themselves constitute a bona fide purchase for value. To occupy that position, the holder must actually have parted with something of value for the note."17 In the American and English Encyclopedia of Law, ${ }^{18}$ it is said: "Where a bank discounts paper for a deprositor who is not in its debt and gives him credit upon its books for the proceeds of such paper, it is not a bona fule holder for value, so as to be protected

\footnotetext{
"Taft v. Quinsiganond .Nat. Bark, 172 Mass. $363,366$.

"Ncg. Inst. Scc. 779 b. 5th Edition.

"Vol 4, 2d Edition.
} 
against infirmities in the paper, unless, in addition to the mere fact of crediting the depositor with the proceeds of the paper, some other and valuable consideration passes. Sucl a transaction simply creates the relation of debtor and creditor between the bank and the depositor."

Passing from these statements of text writers to original sources, ample confirmation is found. In Central $\mathrm{Na}$ tional Bank v. Valentine," the Court said: "The plaintiff by its president discounted the notes and gave the makers credit on the books of the bank for the amount, no money was actually paid or thing of value parted with by the plaintiff upon the strength of the endorsement or the discount. Under such circumstances, the plaintiff cannot be regarded the bona fide holder of said notes for value. $* * *$ The mere giving of credit by entering the amount on the books and not actually parting with a dollar upon the strength of the endorsement, cannot be regarded parting with value in the sense in which the law contemplates. The parties in whose favor the credit was given might never draw or appropriate any portion of the fund."

Fifteen years afterward, the same court said in a case of similar character: "The bank could not become a holder for value of the note by crediting its amount to the cashier. Unless he received the moncy as an individual, and not as cashier, the bank parted with nothing as a consideration for the note." declared concerning a note which had been discounted for the payce who had been credited with the proceeds on the books of the bank: "The plaintiff must have actually paid out and parted with the proceels of the discount before it could accuire an inlisputable title thereto."21 One more citation may be given from the court in the same State; the Appellate Division decided three years ago: "A lank is

\footnotetext{
18 Hun. 417.

* Dykmun v. Northbridge, 8o IHun. 258.

2 Sixth Nutional liank v. Lorillard Brick Il'urks Co., ${ }_{46}^{6}$ N. Y. St. Rochester 235.
} 
not a holker of a note in due course as defined by the Negotiable Instruments Law (which in this regard, follows the common law), when the proceeds of the note are simply. credited to the person from whom it was purchased. ${ }^{22}$ "

It may be further noted that the tribunals of the State which maintain the rule concerning the bona fide ownership of a note that is discounted by a bank which credits the proceeds to the borrower, are the same tribunals which first clearly established the rule concerning the ownership of checks credited to depositors with the right to -draw immediately against the anount credited. This was done in Metropolitan National Bank v. Loyd, by the Supreme Court of New York, whose decision was affirmed by the Court of Appeals and has been often cited to sustain later decisions. Said the Suprene Court in that case: "By the acceptance of the check by the bank receiving it as so much money, it became the debtor to the customer to the extent of the amount credited on account of it. And while he did not draw checks or drafts against it, but the bank was largely his debtor, he still had the right to do it if he had been so disposed. The account, including the amount of the check, stood with his assent as so much money subject to his disposal, and because of that circumstance, he ceased to be the owner of the check, and the title to it became vested in the bank or its own property and subject to its risk in case of loss." ${ }^{23}$ This principle has been often affirmed both by the courts of New York and by those of other States.

Other States have maintained the same rule concerning notes discounted for, and credited to, the account of depositors. One of the latest deliverances is by the Supreme Court of Iowa, in which the court says: "If a bank discounts paper for one of its depositors, giving him credit

z Albany Co. Bank v. Penple's Ire Co., 92 App. Div. 47, 55; Clarke National Bank v. Bank of Albion, 52 Barb. 592 ; Nat. Bank of Barre $v$. Folyy, 103 N. Y. Supp. 5.53.

It ctropolitan Nal. Bank v. Loyd, 25 Hun, 101, 105, affd. 90 N. Y. 530. 
therefor upon its books for the proceeds, it is not a bona fide holder unless some other and valuable consideration passes."24 The Courts of Michigan, ${ }^{25}$ Wisconsin, ${ }^{26}$ Kansas, ${ }^{27}$ have announced the same rule.

In a recent New York case, there is a disposition to bring the check rule into more perfect harmony with that which applies to notes discounted for, and credited to, depositors. After setting forth the four elements needful to constitute a bona fide purchaser by the Negotiable Instruments Law, and that one of these is that the Instrument must have been taken in good faith and for value, the Court says: "The authorities hold that the mere crediting to a depositor's account, on the books of a bank, of the amount of a check drawn upon another bank, where the depositor's account continues to be sufficient to pay the check in case it is dishonored, does not constitute the bank a holder in due course." 28

This clearly marks a departure from the rule in the Loyd Casc, and rests on a different foundation. The change of ownership of the check in the Loyd Case rested on the crediting of it as cash with the inmediate right to draw for the amount, without the slightest regard to the condition of the depositor's account. In the Corelcs Case, such a crediting with the right to draw did not change the ownership of the check, if the depr,sitor's balance was adequate to pay the amount of the check thus credited, had it been drawn out regardless of the credit thus given.

Does not this rule rest on a more rational foundation? Indeed, is there any valid reason for applying a different rule to checks that are credited to their depositors as cish than is applied to notes that are discounted for and credited to depositors? The transactions are similar in every essen-

"City Deposit Bank จ. Green, 130 Iowa $384 ;$ McKnight ४. Parsons, 113 N. W. 858

- Drovers' Nat. Bank v. Blue, yo Mich.; 67 N. W. 1105.

* Manufacturers' Nat. Bank v. Nerihall, 7I Wis. 300.

$n$ Mann v. Second Nat. Bank, 30 Kans. 412.

“Citizens' State Bank v. Coules, 180 N. Y. 346 , revg. 89 Ap. $280^{\circ}$ 
tial respect. In both, the. depositor has a right to draw when he pleases; in both, the debtor and creditor relation exists between him and the bank with respect to the deposit. In the one case, the bank owns or holds the depositor's note; in the other, his check. Its right and control over the one instrument is as perfect as its control over the other. The note can be given up before the money is drawn if the depositor should become insolvent, or, if it was forged, or possesses other infirmity not known when it was riceived, and the credit can be cancelled. A check can be returned if it was forged or otherwise imperfect, and should prove to be uncollectable after using the legally required diligence.

Niay not the decision in the Cowles case be regarded as a return to a more rational view concerning the ownership of a check credited to a depositor with the right to immediate payment? In other words, so long as a depositor checks against his actual cash deposit, he is not borrowing, and the bank is not the bona fide purchaser of checks credited to him, but not collected. When his checks go beyond this line, then the bank becomes the owner either.absolutely, or to the extent of its lien.

Albert S. Bolles. 